\title{
The War on Terrorism and the End of Human Rights
}

David Luban

Georgetown University Law Center, luband@law.georgetown.edu

This paper can be downloaded free of charge from:

https://scholarship.law.georgetown.edu/facpub/892

22 Phil. \& Pub. Pol'y Q. 9-14 (2002)

This open-access article is brought to you by the Georgetown Law Library. Posted with permission of the author. Follow this and additional works at: https://scholarship.law.georgetown.edu/facpub

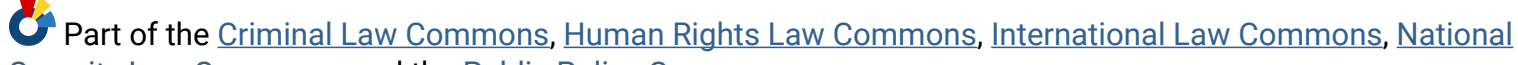
Security Law Commons, and the Public Policy Commons 


\section{The War on Terrorism and the End of Human Rights}

\section{David Luban}

$\mathrm{I}_{\mathrm{P} \text { tes }}^{\mathrm{n}}$ $n$ the immediate aftermath of September 11, President Bush stated that the perpetrators of the deed would be brought to justice. Soon afterwards, the President announced that the United States would engage in a war on terrorism. The first of these statements adopts the familiar language of criminal law and criminal justice. It treats the September 11 attacks as horrific crimes-mass murders-and the government's mission as apprehending and punishing the surviving planners and conspirators for their roles in the crimes. The War on Terrorism is a different proposition, however, and a different model of governmental action-not law but war. Most obviously, it dramatically broadens the scope of action, because now terrorists who knew nothing about September 11 have been earmarked as enemies. But that is only the beginning.

\section{The Hybrid War-Law Approach}

The model of war offers much freer rein than that of law, and therein lies its appeal in the wake of 9/11. First, in war but not in law it is permissible to use

\section{Given Washington's mandate to eliminate the danger of future 9/11s, the model of war offers important advantages over the model of law.}

lethal force on enemy troops regardless of their degree of personal involvement with the adversary. The conscripted cook is as legitimate a target as the enemy general. Second, in war but not in law "collateral damage," that is, foreseen but unintended killing of noncombatants, is permissible. (Police cannot blow up an apartment building full of people because a murderer is inside, but an air force can bomb the building if it contains a military target.) Third, the requirements of evidence and proof are drastically weaker in war than in criminal justice. Soldiers do not need proof beyond a reasonable doubt, or even proof by a preponderance of evidence, that someone is an enemy soldier before fir- ing on him or capturing and imprisoning him. They don't need proof at all, merely plausible intelligence. Thus, the U.S. military remains regretful but unapologetic about its January 2002 attack on the Afghani town of Uruzgan, in which 21 innocent civilians were killed, based on faulty intelligence that they were al Qaeda fighters. Fourth, in war one can attack an enemy without concern over whether he has done anything. Legitimate targets are those who in the course of combat might harm us, not those who have harmed us. No doubt there are other significant differences as well. But the basic point should be clear: given Washington's mandate to eliminate the danger of future $9 / 11$ s, so far as humanly possible, the model of war offers important advantages over the model of law.

There are disadvantages as well. Most obviously, in war but not in law, fighting back is a legitimate response of the enemy. Second, when nations fight a war, other nations may opt for neutrality. Third, because fighting back is legitimate, in war the enemy soldier deserves special regard once he is rendered harmless through injury or surrender. It is impermissible to punish him for his role in fighting the war. Nor can he be harshly interrogated after he is captured. The

$$
\begin{gathered}
\text { By selectively combining elements of the war } \\
\text { model and elements of the law model, } \\
\text { Washington is able to maximize its own ability } \\
\text { to mobilize lethal force against terrorists while } \\
\text { eliminating most traditional rights of a } \\
\text { military adversary. ... }
\end{gathered}
$$

Third Geneva Convention provides: "Prisoners of war who refuse to answer [questions] may not be threatened, insulted, or exposed to unpleasant or disadvantageous treatment of any kind." And, when the war concludes, the enemy soldier must be repatriated.

Here, however, Washington has different ideas, designed to eliminate these tactical disadvantages in the traditional war model. Washington regards international terrorism not only as a military adversary, but 


\section{Genetics and Criminal Behavior}

\author{
David Wasserman and Robert \\ Wachbroit, Editors
}

This volume brings together a group of essays by leading philosophers of science, ethicists, and legal scholars, commissioned for an important and controversial conference on genetics and crime. The essays address basic conceptual, methodological, and ethical issues raised by genetic research on criminal behavior but largely ignored in the public debate. They explore the complexities in tracing any genetic influence on criminal, violent, or antisocial behavior, the varieties of interpretation to which evidence of such influences is subject, and the relevance of such influences to the moral and legal appraisal of criminal conduct. The volume provides a critical overview of the assumptions, methods, and findings of recent behavioral genetics.

Contributors: Robert Wachbroit, Elliott Sober, Kenneth F. Schaffner, Kenneth A. Taylor, Ian Hacking, Allen Gibbard, Marcia Baron, Peter Van Inwagen, Patricia S. Greenspan, Michael Slote, Jorge L.A. Garcia, and David Wasserman.

Cambridge Studies in Philosophy and Public Policy 350 pages

Cloth, $\$ 64.95$

Paper, \$22.95

\begin{abstract}
Cambridge University Press http://www.cup.org
\end{abstract}

For ordering information, telephone:

Tel: 1-800-872-7423 FAX: 914-937-4712 or call:

Customer Service Department 110 Midland Avenue

Port Chester, NY 10573 also as a criminal activity and criminal conspiracy. In the law model, criminals don't get to shoot back, and their acts of violence subject them to legitimate punishment. That is what we see in Washington's prosecution of the War on Terrorism. Captured terrorists may be tried before military or civilian tribunals, and shooting back at Americans, including American troops, is a federal crime (for a statute under which John Walker Lindh was indicted criminalizes anyone regardless of nationality, who "outside the United States attempts to kill, or engages in a conspiracy to kill, a national of the United States" or "engages in physical violence with intent to cause serious bodily injury to a national of the United States; or with the result that serious bodily injury is caused to a national of the United States"). Furthermore, the U.S. may rightly demand that other countries not be neutral about murder and terrorism. Unlike the war model, a nation may insist that those who are not with us in fighting murder and terror are against us, because by not joining our operations they are providing a safe haven for terrorists or their bank accounts. By selectively combining elements of the war model and elements of the law model, Washington is able to maximize its own ability to mobilize lethal force against terrorists while eliminating most traditional rights of a military adversary, as well as the rights of innocent bystanders caught in the crossfire.

\section{A Limbo of Rightlessness}

The legal status of al Qaeda suspects imprisoned at the Guantanamo Bay Naval Base in Cuba is emblematic of this hybrid war-law approach to the threat of terrorism. In line with the war model, they lack the usual rights of criminal suspects-the presumption of innocence, the right to a hearing to determine guilt, the opportunity to prove that the authorities have grabbed the wrong man. But, in line with the law model, they are considered unlawful combatants. Because they are not uniformed forces, they lack the rights of prisoners of war and are liable to criminal punishment. Initially, the American government declared that the Guantanamo Bay prisoners have no rights under the Geneva Conventions. In the face of international protests, Washington quickly backpedaled and announced that the Guantanamo Bay prisoners would indeed be treated as decently as POWs-but it also made clear that the prisoners have no right to such treatment. Neither criminal suspects nor POWs, neither fish nor fowl, they inhabit a limbo of rightlessness. Secretary of Defense Rumsfeld's assertion that the U.S. may continue to detain them even if they are acquitted by a military tribunal dramatizes the point.

To understand how extraordinary their status is, consider an analogy. Suppose that Washington declares a War on Organized Crime. Troops are dis- 
patched to Sicily, and a number of Mafiosi are seized, brought to Guantanamo Bay, and imprisoned without a hearing for the indefinite future, maybe the rest of their lives. They are accused of no crimes, because their capture is based not on what they have done but on what they might do. After all, to become "made" they took oaths of obedience to the bad guys. Seizing them accords with the war model: they are enemy foot soldiers. But they are foot soldiers out of uniform; they lack a "fixed distinctive emblem," in the words of The Hague Convention. That makes them unlawful combatants, so they lack the rights of POWs. They may object that it is only a unilateral declaration by the American President that has turned them into combatants in the first place- - he called it a war, they didn'tand that, since they do not regard themselves as literal foot soldiers it never occurred to them to wear a fixed distinctive emblem. They have a point. It seems too easy for the President to divest anyone in the world of rights and liberty simply by announcing that the U.S. is at war with them and then declaring them unlawful combatants if they resist. But, in the hybrid war-law model, they protest in vain.

Consider another example. In January 2002, U.S. forces in Bosnia seized five Algerians and a Yemeni suspected of al Qaeda connections and took them to Guantanamo Bay. The six had been jailed in Bosnia, but a Bosnian court released them for lack of evidence,

\section{It seems too easy for the President to divest anyone in the world of rights and liberty simply by announcing that the U.S. is at war with them and then declaring them unlawful combatants if they resist.}

and the Bosnian Human Rights Chamber issued an injunction that four of them be allowed to remain in the country pending further legal proceedings. The Human Rights Chamber, ironically, was created under U.S. auspices in the Dayton peace accords, and it was designed specifically to protect against treatment like this. Ruth Wedgwood, a well-known international law scholar at Yale and a member of the Council on Foreign Relations, defended the Bosnian seizure in war-model terms. "I think we would simply argue this was a matter of self-defense. One of the fundamental rules of military law is that you have a right ultimately to act in self-defense. And if these folks were actively plotting to blow up the U.S. embassy, they should be considered combatants and captured as combatants in a war." Notice that Professor Wedgwood argues in terms of what the men seized in Bosnia were planning to do, not what they did; notice as well that the decision of the Bosnian court that there was insufficient evidence does not matter. These are characteristics of the war model.

More recently, two American citizens alleged to be al Qaeda operatives (Jose Padilla, a.k.a. Abdullah al Muhajir, and Yasser Esam Hamdi) have been held in American military prisons, with no crimes charged, no opportunity to consult counsel, and no hearing. The President described Padilla as "a bad man" who aimed to build a nuclear "dirty" bomb and use it against America; and the Justice Department has classified both men as "enemy combatants" who may be held indefinitely. Yet, as military law expert Gary Solis points out, "Until now, as used by the attorney general, the term 'enemy combatant' appeared nowhere in U.S. criminal law, international law or in the law of war." The phrase comes from the 1942 Supreme Court case Ex parte Quirin, but all the Court says there is that "an enemy combatant who without uniform comes secretly through the lines for the purpose of waging war by destruction of life or property" would "not... be entitled to the status of prisoner of war, but... [they

\section{Under circumstances of such dire menace, it is appropriate to treat terrorists as though they embody the most dangerous aspects of both warriors and criminals.}

would] be offenders against the law of war subject to trial and punishment by military tribunals." For the Court, in other words, the status of a person as a nonuniformed enemy combatant makes him a criminal rather than a warrior, and determines where he is tried (in a military, rather than a civilian, tribunal) but not whether he is tried. Far from authorizing open-ended confinement, Ex parte Quirin presupposes that criminals are entitled to hearings: without a hearing how can suspects prove that the government made a mistake? Quirin embeds the concept of "enemy combatant" firmly in the law model. In the war model, by contrast, POWs may be detained without a hearing until hostilities are over. But POWs were captured in uniform, and only their undoubted identity as enemy soldiers justifies such open-ended custody. Apparently, Hamdi and Padilla will get the worst of both modelsopen-ended custody with no trial, like POWs, but no certainty beyond the U.S. government's say-so that they really are "bad men." This is the hybrid war-law model. It combines the Quirin category of "enemy combatant without uniform," used in the law model to justify a military trial, with the war model's practice of indefinite confinement with no trial at all. 


\section{The Case for the Hybrid Approach}

Is there any justification for the hybrid war-law model, which so drastically diminishes the rights of the enemy? An argument can be offered along the following lines. In ordinary cases of war among states, enemy soldiers may well be morally and politically innocent. Many of them are conscripts, and those who aren't do not necessarily endorse the state policies they are fighting to defend. But enemy soldiers in the War on Terrorism are, by definition, those who have embarked on a path of terrorism. They are neither morally nor politically innocent. Their sworn aim"Death to America!" - is to create more 9/11s. In this respect, they are much more akin to criminal conspirators than to conscript soldiers. Terrorists will fight as soldiers when they must, and metamorphose into mass murderers when they can.

Furthermore, suicide terrorists pose a special, unique danger. Ordinary criminals do not target innocent bystanders. They may be willing to kill them if necessary, but bystanders enjoy at least some measure of security because they are not primary targets. Not so with terrorists, who aim to kill as many innocent people as possible. Likewise, innocent bystanders are protected from ordinary criminals by whatever deterrent force the threat of punishment and the risk of getting killed in the act of committing a crime offer. For a suicide bomber, neither of these threats is a deterrent at all-after all, for the suicide bomber one of the hallmarks of a successful operation is that he winds up dead at day's end. Given the unique and heightened danger that suicide terrorists pose, a stronger response that grants potential terrorists fewer rights may be justified. Add to this the danger that terrorists may come to possess weapons of mass destruction, including nuclear devices in suitcases. Under circumstances of such dire menace, it is appropriate to treat terrorists as though they embody the most dangerous aspects of both warriors and criminals. That is the basis of the hybrid war-law model.

\section{The Case against Expediency}

The argument against the hybrid war-law model is equally clear. The U.S. has simply chosen the bits of the law model and the bits of the war model that are most convenient for American interests, and ignored the rest. The model abolishes the rights of potential enemies (and their innocent shields) by fiat-not for reasons of moral or legal principle, but solely because the U.S. does not want them to have rights. The more rights they have, the more risk they pose. But Americans' urgent desire to minimize our risks doesn't make other people's rights disappear. Calling our policy a War on Terrorism obscures this point.
The theoretical basis of the objection is that the law model and the war model each comes as a package, with a kind of intellectual integrity. The law model grows out of relationships within states, while the war model arises from relationships between states. The law model imputes a ground-level community of values to those subject to the law-paradigmatically, citizens of a state, but also visitors and foreigners who choose to engage in conduct that affects a state. Only because law imputes shared basic values to the community can a state condemn the conduct of criminals and inflict punishment on them. Criminals deserve condemnation and punishment because their conduct violates norms that we are entitled to count on their sharing. But, for the same reason-the imputed community of values - those subject to the law ordinarily enjoy a presumption of innocence and an expectation of safety. The government cannot simply grab them and confine them without making sure they have bro-

\section{Americans' urgent desire to minimize our risks doesn't make other people's rights disappear. Calling our policy a War on Terrorism obscures this point.}

ken the law, nor can it condemn them without due process for ensuring that it has the right person, nor can it knowingly place bystanders in mortal peril in the course of fighting crime. They are our fellows, and the community should protect them just as it protects us. The same imputed community of values that justifies condemnation and punishment creates rights to due care and due process.

War is different. War is the ultimate acknowledgment that human beings do not live in a single community with shared norms. If their norms conflict enough, communities pose a physical danger to each other, and nothing can safeguard a community against its enemies except force of arms. That makes enemy soldiers legitimate targets; but it makes our soldiers legitimate targets as well, and, once the enemy no longer poses a danger, he should be immune from punishment, because if he has fought cleanly he has violated no norms that we are entitled to presume he honors. Our norms are, after all, our norms, not his.

Because the law model and war model come as conceptual packages, it is unprincipled to wrench them apart and recombine them simply because it is in America's interest to do so. To declare that Americans can fight enemies with the latitude of warriors, but if the enemies fight back they are not warriors but criminals, amounts to a kind of heads-I-win-tails-you-lose international morality in which whatever it takes to 
reduce American risk, no matter what the cost to others, turns out to be justified. This, in brief, is the criticism of the hybrid war-law model.

To be sure, the law model could be made to incorporate the war model merely by rewriting a handful of statutes. Congress could enact laws permitting imprisonment or execution of persons who pose a significant threat of terrorism whether or not they have already done anything wrong. The standard of evidence could be set low and the requirement of a hearing eliminated. Finally, Congress could authorize the use of lethal force against terrorists regardless of the danger to innocent bystanders, and it could immunize officials from lawsuits or prosecution by victims of collateral damage. Such statutes would violate the Constitution, but the Constitution could be amended to incorporate anti-terrorist exceptions to the Fourth, Fifth, and Sixth Amendments. In the end, we would have a system of law that includes all the essential features of the war model.

It would, however, be a system that imprisons people for their intentions rather than their actions, and that offers the innocent few protections against mistaken detention or inadvertent death through collateral damage. Gone are the principles that people should never be punished for their thoughts, only for their deeds, and that innocent people must be protected rather than injured by their own government. In that sense, at any rate, repackaging war as law seems merely cosmetic, because it replaces the ideal of law as a protector of rights with the more problematic goal of protecting some innocent people by sacrificing others. The hypothetical legislation incorporates war into law only by making law as partisan and ruthless as war. It no longer resembles law as Americans generally understand it.

\section{The Threat to International Human Rights}

In the War on Terrorism, what becomes of international human rights? It seems beyond dispute that the war model poses a threat to international human rights, because honoring human rights is neither practically possible nor theoretically required during war. Combatants are legitimate targets; non-combatants maimed by accident or mistake are regarded as collateral damage rather than victims of atrocities; cases of mistaken identity get killed or confined without a hearing because combat conditions preclude due process. To be sure, the laws of war specify minimum human rights, but these are far less robust than rights in peacetime-and the hybrid war-law model reduces this schedule of rights even further by classifying the enemy as unlawful combatants.

One striking example of the erosion of human rights is tolerance of torture. It should be recalled that a 1995 al Qaeda plot to bomb eleven U.S. airliners was thwarted by information tortured out of a Pakistani suspect by the Philippine police-an eerie real-life version of the familiar philosophical thought-experiment. The Washington Post reports that since September 11 the U.S. has engaged in the summary transfer of dozens of terrorism suspects to countries where they will be interrogated under torture. But it isn't just the United States that has proven willing to tolerate torture for security reasons. Last December, the Swedish government snatched a suspected Islamic extremist to whom it had previously granted political asylum, and the same day had him transferred to Egypt, where Amnesty International reports that he has been tortured to the point where he walks only with difficulty. Sweden is not, to say the least, a traditionally hard-line nation on human rights issues. None of this international transportation is lawful-indeed, it violates international treaty obligations under the Convention against Torture that in the U.S. have constitutional status as "supreme Law of the Land"-but that may not matter under the war model, in which even constitutional rights may be abrogated.

It is natural to suggest that this suspension of human rights is an exceptional emergency measure to deal with an unprecedented threat. This raises the question of how long human rights will remain suspended. When will the war be over?

Here, the chief problem is that the War on Terrorism is not like any other kind of war. The enemy, Terrorism, is not a territorial state or nation or government. There is no opposite number to negotiate with. There is no one on the other side to call a truce or declare a ceasefire, no one among the enemy authorized to surrender. In traditional wars among states, the war aim is, as Clausewitz argued, to impose one state's political will on another's. The aim of the war is not to kill the enemy-killing the enemy is the means used to achieve the real end, which is to force capitulation. In the War on Terrorism, no capitulation is possible. That means that the real aim of the war is, quite simply, to kill or capture all of the terrorists-to keep on killing and killing, capturing and capturing, until they are all gone.

Of course, no one expects that terrorism will ever disappear completely. Everyone understands that new anti-American extremists, new terrorists, will always arise and always be available for recruitment and deployment. Everyone understands that even if al Qaeda is destroyed or decapitated, other groups, with other leaders, will arise in its place. It follows, then, that the War on Terrorism will be a war that can only be abandoned, never concluded. The War has no natural resting point, no moment of victory or finality. It requires a mission of killing and capturing, in territories all over the globe, that will go on in perpetuity. It 
follows as well that the suspension of human rights implicit in the hybrid war-law model is not temporary but permanent.

Perhaps with this fear in mind, Congressional authorization of President Bush's military campaign limits its scope to those responsible for September 11 and their sponsors. But the War on Terrorism has taken on a life of its own that makes the Congressional authorization little more than a technicality. Because of the threat of nuclear terror, the American leadership actively debates a war on Iraq regardless of whether Iraq was implicated in September 11; and the President's yoking of Iraq, Iran, and North Korea into a single axis of evil because they back terror suggests that the War on Terrorism might eventually encompass all these nations. If the U.S. ever unearths tangible evidence that any of these countries is harboring or abetting terrorists with weapons of mass destruction, there can be little doubt that Congress will support military action. So too, Russia invokes the American War on Terrorism to justify its attacks on Chechen rebels, China uses it to deflect criticisms of its campaign against Uighur separatists, and Israeli Prime Minister Sharon explicitly links military actions against Palestinian insurgents to the American War on Terrorism. No doubt there is political opportunism at work in some or all of these efforts to piggy-back onto America's campaign, but the opportunity would not exist if "War on Terrorism" were merely the code-name of a discrete, neatly-boxed American operation. Instead, the War on Terrorism has become a model of politics, a world-view with its own distinctive premises and consequences. As I have argued, it includes a new model of state action, the hybrid war-law model, which depresses human rights from their peace-time standard to the war-time standard, and indeed even further. So long as it continues, the War on Terrorism means the end of human rights, at least for those near enough to be touched by the fire of battle.

David Luban

Frederick Haas Professor of Law and Philosophy Georgetown University Law Center luband@law.georgetown.edu

Sources: On the January 2002 attack on the Afghani town of Uruzgan, see: John Ward Anderson, "Afghans Falsely Held by U.S. Tried to Explain; Fighters Recount Unanswered Pleas, Beatings-and an Apology on Their Release," Washington Post (March 26, 2002); see also Susan B. Glasser, "Afghans Live and Die With U.S. Mistakes; Villagers Tell of Over 100 Casualties," Washington Post (Feb. 20, 2002). On the Third
Geneva Convention, see: Geneva Convention (III) Relative to the Treatment of Prisoners of War, 6 U.S.T. 3317, signed on August 12, 1949, at Geneva, Article 17. Although the U.S. has not ratified the Geneva Convention, it has become part of customary international law, and certainly belongs to the war model. Count One of the Lindh indictment charges him with violating 18 U.S.C. 2332(b), "Whoever outside the United States attempts to kill, or engages in a conspiracy to kill, a national of the United States" may be sentenced to 20 years (for attempts) or life imprisonment (for conspiracies). Subsection (c) likewise criminalizes "engag[ing] in physical violence with intent to cause serious bodily injury to a national of the United States; or with the result that serious bodily injury is caused to a national of the United States." Lawful combatants are defined in the Hague Convention (IV) Respecting the Laws and Customs of War on Land, Annex to the Convention, 1 Bevans 631, signed on October 18, 1907, at The Hague, Article 1. The definition requires that combatants "have a fixed distinctive emblem recognizable at a distance." Protocol I Additional to the Geneva Conventions of 1949, 1125 U.N.T.S. 3, adopted on June 8, 1977, at Geneva, Article 44 (3) makes an important change in the Hague Convention, expanding the definition of combatants to include non-uniformed irregulars. However, the United States has not agreed to Protocol I. The source of Ruth Wedgwood's remarks: Interview with Melissa Block, National Public Radio program, "All Things Considered" (January 18, 2002); Gary Solis, "Even a 'Bad Man' Has Rights," Washington Post ( June 25, 2002); Ex parte Quirin, 317 U.S. 1, 31 (1942). On the torture of the Pakistani militant by Philippine police: Doug Struck et al., "Borderless Network Of Terror; Bin Laden Followers Reach Across Globe," Washington Post (September 23, 2001): "'For weeks, agents hit him with a chair and a long piece of wood, forced water into his mouth, and crushed lighted cigarettes into his private parts,' wrote journalists Marites Vitug and Glenda Gloria in 'Under the Crescent Moon,' an acclaimed book on Abu Sayyaf. 'His ribs were almost totally broken and his captors were surprised he survived.'" On U.S. and Swedish transfers of Isamic militants to countries employing torture: Rajiv Chandrasakaran \& Peter Finn, "U.S. Behind Secret Transfer of Terror Suspects," Washington Post (March 11, 2002); Peter Finn, "Europeans Tossing Terror Suspects Out the Door," Washington Post (January 29, 2002); Anthony Shadid, "Fighting Terror/Atmosphere in Europe, Military Campaign /Asylum Bids; in Shift, Sweden Extradites Militants to Egypt," Boston Globe (December 31, 2001). Article $3(1)$ of the Convention against Torture provides that "No State Party shall expel, return ('refouler') or extradite a person to another State where there are substantial grounds for believing that he would be in danger of being subjected to torture." Article 2(2) cautions that "No exceptional circumstances whatsoever, whether a state of war or a threat of war, internal political instability or any other public emergency, may be invoked as a justification of torture." But no parallel caution is incorporated into Article 3(1)'s non-refoulement rule, and a lawyer might well argue that its absence implies that the rule may be abrogated during war or similar public emergency. Convention against Torture and Other Cruel, Inhuman or Degrading Treatment or Punishment, 1465 U.N.T.S. 85. Ratified by the United States, Oct. 2, 1994. Entered into force for the United States, Nov. 20, 1994. (Article VI of the U.S. Constitution provides that treaties are the "supreme Law of the Land.") 